\title{
THE RELATIONSHIP BETWEEN FARM SIZE AND PRODUCTIVITY IN SLOVAKIA
}

\section{Jana Ladvenicová*, Silvia Miklovičová}

\author{
Slovak University of Agriculture in Nitra, Slovakia
}

The paper investigates the relationship between farm size and productivity on chosen sample of companies in Slovakia. The impact of farm size in hectares and credits per hectare in euro on the production per hectare are analysed. The ordinary least square (OLS) and fixed effect model (FEM) regression framework confirms the inverse relationship between farm size and productivity. Credits per hectare have positive impact on productivity of farms. The results of the models show increasing returns to scale in Slovak farms.

Keywords: farms, farm size, productivity, panel data, regression analysis

\section{Introduction}

In the Slovak Republic, the average farm has around 521.5 ha of utilised agricultural area. It is the largest area from all EU countries. In the Slovak Republic, the utilised agricultural area is cultivated by small number of farms which operate on large land area. This situation is really unique in the EU. Average utilised agricultural land is around 33 ha per farm and just in other 4 countries, there is the concentration of utilised land area more than 100 ha per farm - the Czech Republic (227.86 ha), the United Kingdom (161.13 ha), Estonia (125.87 ha) and Sweden (101.27 ha). According to the statistical data, the Slovak Republic has the first place in area of utilised land which farmers rent. Average European farmer rents around 18 ha of utilised agricultural land - it is around $55 \%$ of the total agricultural area on which a farmer operates. A Slovak farmer rents about $95 \%$ of agricultural land on which he/she operates. In absolute value, it is 495.3 ha per farm. Productivity of farms can be represented by many indicators, for instance output, value added or revenue per hectare. According to FADN database, the total crops output per hectare in a Slovak average farm was 582.89 euro in 2012. It is one of the lowest amounts of EU-27 (Ireland $251.68 €$ ha $^{-1}$ and Luxembourg $537.87 € \mathrm{ha}^{-1}$ ). Average sales from own products and services was $682.1 € \mathrm{ha}^{-1}$ and value added $44.1 € \mathrm{ha}^{-1}$.

The relationship between farm size and output is one of the basic questions in development economics which was already solved in many research studies. It is well known as the inverse relationship between farm productivity and farm size. The aim of the following relation between farm size and output is to answer the question if large farms are more productive than the small ones. The first studies showed that there exists the inverse relationship between productivity and farm size and we can say that small farms are more productive than large farms (Ciaian, 2012).

After the 1960s, Farm Management Surveys in India as the first ones established the empirical basis for following the inverse relationship. Since then, the evidence has been so widely observed by many others in different countries that the inverse relation is considered a "stylized fact" of agriculture in developing countries [(Heltberg, 1998) for Pakistan; (Berry and Cline, 1979) for Brazil, Colombia, the Philippines, Pakistan, India, and Malaysia; (Sen, 1981) for India; (Carter, 1984) for Haryana in the North India; (Kutcher and Scandizzo, 1981) for the North East Brazil; (Benjamin, 1995) for Java; and (Masterson, 2005) for Paraguay].

The inverse size-yield has many crucial and far-reaching implications for rural development policy, which is in part why it has gotten considerable attention from development researchers. The most prominent implication is that it may provide economic justification for redistributive land reforms, as policies to correct the inverse relation imply both allocations of efficiency and equity at the same time. If land productivity is higher in small farms and rural factor markets are not correcting the inverse relation, then policies to eliminate inverse relation and promote economic growth call for redistributive land reforms (Ünal Gül, 2008). Land reforms have played a very important role in economic transformation, creating agricultural surplus, growing consumer demand, and creating political stability to maintain rapid industrialization for many countries (Heltberg, 1998). Another important implication of the inverse relation in rural development policy is outcome for employment, deteriorating environmental conditions and disintegrating communities.

Sen (1962) in his research observed the inverse relationship between farm size and productivity (represented by output per hectare) in Indian agriculture. The result of his research was that small farms are more productive compared to larger farms. This relationship can be explained by the relative advantage of using more family labour by small farms that may reduce the monitoring and supervising of hired labour costs (Thapa, 2007). According to Feder (1985) small farmers have high labour/land ratios, and could achieve higher yield per hectare. Moreover, the inverse relationship is typically explained by the failure of rural markets for credit, labour and land, as well as by the difference in labour endowments between small and large farms.

Fan and Connie (2005) show that to increase labour productivity, and therefore, farmer's income, either land productivity has to increase or land to labour ratio has to improve. Given the consensus that smaller farms have a lower land-labour ratio than large farms, Havnevik and Skarstein (1997) argue that smaller farms enjoy higher land productivity in the short-term, but over the long-term, land productivity tends to drop. They argue that this long-term drop in land productivity results from over-intensive cultivation of the land in order to maintain labour productivity, when more and more people need to survive on the same small area of farmland, and as the smaller farms are resource-poor to invest in preserving soil fertility, soil productivity eventually becomes exhausted and land productivity drops.

Neoclassical theorists argue that the segmentation of land, credit, and labour markets results in the inverse relationship. Large landowners have access to land and credit that small farmers do not. However, this segmentation implies that larger farms are more capital intensive, which should theoretically decrease the inverse relationship. While larger farms generally have higher land to labour and capital to labour ratios, they do not 
necessarily have higher capital to land ratios. If the capital to land ratio is higher for large farms, then the inverse relationship is weakened (Dyer, 1996).

Credit markets in many less-developed countries are characterized by undeveloped financial institutions (small farmers have high interest rate of loans and credits go to richer peasants), the cost of and access to credits are inversely related to farm size. This credit market segmentation favours the reduction of the inverse relationship. Labour market segmentation, on the other hand, may intensify the inverse relationship. Segmentation in input markets may also tend to diminish the inverse relationship if larger farmers have first access to long-term asset etc. (Cornia, 1985).

According to Masterson (2007), land quality differences may contribute to the inverse relationship. More output may lead to greater population growth in areas with greater land quality, which could lead to greater fragmentation and, thus, smaller farms. Land quality differences have two possible sources: natural differences in soil types, climate, etc.; and man-made differences, due to investments in fertilizers, soil conservation, etc. In the latter case, small farm size could lead to better quality land, not the other way around. Smaller farms may be more likely to make labour intensive investments in soil quality.

Differences in quality of land (Bhalla, 1979; Bhalla, 1988; Bhalla and Roy, 1988) and differences in cropping patterns (Bharadwaj, 1974; Fafchamps, 1982) have been argued to explain the productivity differentials between smallholders and large size farms. Verma and Bromley (1987) attribute differences in farm organization, tenancy relations, and differential access to lands of differing quality as consequential for observed productivity differences. Another substantive argument that has been extended to support violation of the inverse farm size-productivity hypothesis is the popular wisdom that having alternative (non- farm) income source gives the larger farm size groups a higher farm expenditure possibility in comparison to those cultivators who have limited or no income diversification opportunities. Association between agrarian class structure (Roemer, 1982) and returns to cultivation has also been attempted at (Desai et al., 2010).

\section{Material and methods}

The aim of our paper is to check whether the relationship between farm size and productivity is negatively related and statistically significant as it is presented in the literature. Most of the researchers' studies derive a negative relationship between farm size and productivity. It means that an increase of farm size leads to a decrease of farm productivity and in this case smaller farms are more productive than large ones. From literature review, the following hypothesis follows:

$\square$ production is negatively related to farm size,

$\square$ production is positively related to credits.

In econometrics model we use balanced panel data which is represented by time and individual dimension. The time dimension is marked as $\mathrm{t}$ and individual dimension is marked as i. In our case we follow the farms in each region of the Slovak Republic which is the individual dimension $i=1, \ldots, N(N$ is 1196 farms in each year of the followed period). These observations are for time period of 9 years, $t$

Table 1 Econometric model variables

\begin{tabular}{l|l|l|}
\multicolumn{2}{|c}{$\begin{array}{c}\text { Dependent variable } \\
\text { Output }\end{array}$} \\
\hline \multicolumn{1}{|l}{ Independent variables } \\
\hline Land & $\square$ output per hectare represented by revenue item - production \\
\hline Credits & $\square$ total amount of farms credits in euro per hectares \\
\hline Dummy variables & \\
\hline Legal form & $\square$ cooperative or commercial company \\
\hline Natural Conditions & $\square$ farms operate in less favoured areas and productive areas \\
\hline Regions of the SR & $\square$ farms in Slovak Regions (Trnava, Nitra, Trenčin, Žlina, Prešov, Banská Bystrica, Prešov, Košice)* \\
\hline Year & \\
\hline$u_{n}$ & $\square$ random error
\end{tabular}

* In Dummy variables there is not Bratislava Region, it means that coefficients represents the difference in comparison with this region (by fixed effect model we do not use these variables because they do not change in time)
$=1, \ldots, T$ (years 2004-2012). The data is used from the Information Letters of the Research Institute of Agricultural and Food Economics in Bratislava. The sample of companies is created from agricultural cooperatives and joint-stocks companies operating in the Regions of Slovakia. Companies of Bratislava, Trnava and Nitra Regions operate in productive areas. Companies of Žilina, Banská Bystrica, Prešov and Košice Regions operate in less favoured areas. Mostly, the crop production predominates over the livestock production except of the Žilina Region and the Prešov Region. The share of crop production is more than $50 \%$ in agricultural cooperatives and more than $60 \%$ in joint-stocks companies. As many as 68 companies operate on the area from 0 to 50 ha, 57 companies operate on the area from 51 to 100 ha, 295 companies operate on the area from 101 to 500 ha, 313 companies operate on area from 501-1000 ha and 463 companies operate on the area of more than 1,000 ha. For quantification of econometric model parameters, the statistical software STATA is used, and for coefficient estimation we use the least-squares method and fixed effect model.

A popular formulation used to test the relationship between farm size and a measure of productivity is based on the simple model:

$$
y=\alpha+\beta \ln A+\varepsilon
$$

where:

$y$ is output per hectare, In $A$ is logarithm of farm area planted and $\varepsilon$ is disturbance term. A negative value of $\beta$ in this specification represents the inverse relationship between farm size and productivity. Later studies included other coefficients to control for the effects of household versus hired labour, land quality and availability of credit (Gilligen, 1998).

The model used for testing inverse relationship in our study is the followed equation:

$\ln$ (output per ha) $)_{i}=\beta_{i}+\ln \beta_{1}($ Iand) + $+\ln \beta_{2}$ (land $\times$ land $)+\ln \beta_{3}$ (credits per ha $)+$ $\beta_{4}$ (legal form $)+\beta_{5}(L F A)+\beta_{6}(T T)+\beta_{7}(N R)+$

$$
\begin{gathered}
\beta_{8}(T N)+\beta_{9}(Z A)+\beta_{10}(B B)+\beta_{11}(P O)+ \\
+\beta_{12}(K E)+\beta_{13}(\text { year })+u_{i 1}
\end{gathered}
$$

\section{Results and discussion}

We quantified the dependence of agricultural output of farmers on the size of farms and credits per hectare by regression analyses. Legal form, natural conditions (less favoured areas or productive areas), regions of the Slovak Republic 
Table 2 Logarithm model-Ordinary Least Squares

\begin{tabular}{|c|c|c|c|c|c|}
\hline Variables & $\begin{array}{c}\text { (1) } \\
\text { In_output_ha }\end{array}$ & $\begin{array}{c}\text { (2) } \\
\text { In_output_ha }\end{array}$ & $\begin{array}{c}\text { (3) } \\
\text { In_output_ha }\end{array}$ & $\begin{array}{c}\text { (4) } \\
\text { In_output_ha }\end{array}$ & $\begin{array}{c}\text { (5) } \\
\text { In_output_ha }\end{array}$ \\
\hline In_land & $\begin{array}{c}-0.171^{* * *} \\
(0.0180)\end{array}$ & $\begin{array}{l}-1.909^{* * *} \\
(0.0942)\end{array}$ & $\begin{array}{c}-1.701^{* * *} \\
(0.0924)\end{array}$ & $\begin{array}{c}-1.703^{* * *} \\
(0.0917)\end{array}$ & $\begin{array}{c}-1.699^{* * *} \\
(0.0917)\end{array}$ \\
\hline In_land_sq & - & $\begin{array}{l}0.150^{* * *} \\
(0.00756)\end{array}$ & $\begin{array}{l}0.135^{* * *} \\
(0.00736)\end{array}$ & $\begin{array}{l}0.135^{* * *} \\
(0.00730)\end{array}$ & $\begin{array}{l}0.135^{* * *} \\
(0.00730)\end{array}$ \\
\hline In_credits_ha & $\begin{array}{l}0.0226^{* * *} \\
(0.00235)\end{array}$ & $\begin{array}{l}0.0196^{* * *} \\
(0.00224)\end{array}$ & $\begin{array}{l}0.0173^{* * *} \\
(0.00204)\end{array}$ & $\begin{array}{l}0.0164^{* * *} \\
(0.00201)\end{array}$ & $\begin{array}{l}0.0164^{* * *} \\
(0.00201)\end{array}$ \\
\hline Legal form & $\begin{array}{l}0.121^{* * *} \\
(0.0317)\end{array}$ & $\begin{array}{c}0.0856^{* * *} \\
(0.0301)\end{array}$ & $\begin{array}{l}0.121^{* * *} \\
(0.0270)\end{array}$ & $\begin{array}{l}0.112^{* * *} \\
(0.0267)\end{array}$ & $\begin{array}{l}0.112^{* * *} \\
(0.0267)\end{array}$ \\
\hline Natural Conditions & - & - & $\begin{array}{c}-1.001^{* * *} \\
(0.0251)\end{array}$ & $\begin{array}{c}-0.289^{* * *} \\
(0.102)\end{array}$ & $\begin{array}{c}-0.271^{* * *} \\
(0.102)\end{array}$ \\
\hline TT & - & - & - & $\begin{array}{l}-0.0350 \\
(0.0786)\end{array}$ & $\begin{array}{l}-0.0326 \\
(0.0788)\end{array}$ \\
\hline NR & - & - & - & $\begin{array}{c}-0.203^{* * *} \\
(0.0778)\end{array}$ & $\begin{array}{c}-0.202^{* * *} \\
(0.0779)\end{array}$ \\
\hline TN & - & - & - & $\begin{array}{l}-0.169 \\
(0.117)\end{array}$ & $\begin{array}{l}-0.183 \\
(0.117)\end{array}$ \\
\hline ZA & - & - & - & $\begin{array}{c}-0.904^{* * *} \\
(0.134)\end{array}$ & $\begin{array}{c}-0.920^{* * *} \\
(0.133)\end{array}$ \\
\hline BB & - & - & - & $\begin{array}{c}-0.951^{* * *} \\
(0.129)\end{array}$ & $\begin{array}{c}-0.967^{* * *} \\
(0.128)\end{array}$ \\
\hline PO & - & - & - & $\begin{array}{c}-1.051^{* * *} \\
(0.127)\end{array}$ & $\begin{array}{c}-1.067^{* * *} \\
(0.126)\end{array}$ \\
\hline KE & - & - & - & $\begin{array}{c}-0.801^{* * *} \\
(0.127)\end{array}$ & $\begin{array}{c}-0.816^{* * *} \\
(0.127)\end{array}$ \\
\hline Year & - & - & - & - & $\begin{array}{c}-0.0321^{* * *} \\
(0.00732)\end{array}$ \\
\hline Constant & $\begin{array}{c}7.583^{* * *} \\
(0.123)\end{array}$ & $\begin{array}{c}12.27 * * * \\
(0.291)\end{array}$ & $\begin{array}{c}12.09^{* * *} \\
(0.286)\end{array}$ & $\begin{array}{c}12.18^{* * *} \\
(0.291)\end{array}$ & $\begin{array}{c}76.62^{* * *} \\
(14.70)\end{array}$ \\
\hline Observations & 7101 & 7101 & 7101 & 7101 & 7101 \\
\hline R-squared & 0.038 & 0.116 & 0.266 & 0.298 & 0.300 \\
\hline
\end{tabular}

Source: Own calculation

Robust standard errors in parentheses; ${ }^{* * *} p<0.01$; ${ }^{* *} p<0.05,{ }^{*} p<0.1$

and year were chosen as Dummy variables. Output of farmers is represented by revenue item - production per hectare of agricultural land. Size of farms is represented by the size of land on which farmers operated during the analysed period. Number of observation was 1196 farms for regions of the Slovak Republic and the followed period was 2004-2012.

In the first model, we worked with 2 independent variables - land and credits per hectare and with one Dummy variable and it was legal form. According to the results of this model we can say that an increase of farm size of about $1 \%$ will lead to a decrease of output by about $17.1 \%$. The positive influence on the agricultural output was shown by credits. The increase of credits by about $1 \%$ causes the increase of output per hectare by about $2.26 \%$. The production per hectare was higher by legal form - cooperatives about $12.1 \%$ in comparison with joint-stocks companies. All variables in this model were statistically significant at significance level $p<0.01$.

In the second model, independent variable - land was added. The results of this model showed us that increase of farm size by about $1 \%$ has negative impact on the output per hectare and it was in amount of about $191 \%$. If the credits will grow by about $1 \%$, the value of output increases by about $2 \%$. Cooperatives reached higher output per hectare by about $8.56 \%$ in comparison with joint-stocks companies. Similar as in the first model, all variables were statistically significant at significance level $p<0.01$.

The natural conditions were added into the third model as Dummy variable. Farm size marked negative influence on the output per hectare again. The farm size decreased the output per hectare by about $170 \%$ by its increasing by about $1 \%$. Positive impact can be again seen by credits. The credits growth by about $1 \%$ will lead to increase of output per hectare byabout $1.73 \%$. Output per hectare was lower by farmers operated in less favoured areas by about $100 \%$ in comparison with farmers operating in productive areas. Legal form of cooperatives had higher production per hectare by about $12.1 \%$.

The fourth model consists of Dummy variables, variable - Regions of the Slovak Republic except of the Bratislava Region. Then the Regions' coefficients represent the difference from the coefficient of the Bratislava Region. Farm size had again negative impact on the output per hectare and it was in amount of $170.3 \%$ by its increase about $1 \%$. Positive influence was shown by credits. The credits increased the value of output per hectare by about $1.64 \%$ if credits increase by about $1 \%$. The output per hectare was higher by cooperatives as by joint-stocks companies. Farmers operating in LFA reached lower output per hectare by about 28-9\% in comparison with farmers operating in productive areas. The highest difference between outputs per hectare in Regions of the Slovak Republic in comparison with the Bratislava Region was shown in the Regions of less favoured areas - Prešov, Žilina and Banská Bystrica Regions.

The last model includes the Dummy variable - year. It means that the value of output in the time decreased by about $3.21 \%$ (statistical significant by $p<0.01)$. In comparison with the fourth model there are not huge differences 
Table 3 Logarithm model - Fixed effects model

\begin{tabular}{|c|c|c|c|c|}
\hline Variables & $\begin{array}{c}\text { (1) } \\
\text { In_output_ha }\end{array}$ & $\begin{array}{c}\text { (2) } \\
\text { In_output_ha }\end{array}$ & $\begin{array}{c}\text { (3) } \\
\text { In_output_ha }\end{array}$ & $\begin{array}{c}\text { (4) } \\
\text { In_output_ha }\end{array}$ \\
\hline In_land & $\begin{array}{c}-0.106^{* * *} \\
(0.0201)\end{array}$ & $\begin{array}{c}-1.682^{* * *} \\
(0.109)\end{array}$ & $\begin{array}{c}-1.681^{* * *} \\
(0.109)\end{array}$ & $\begin{array}{c}-1.673^{* * *} \\
(0.109)\end{array}$ \\
\hline In_land_sq & - & $\begin{array}{l}0.138^{* * *} \\
(0.00903)\end{array}$ & $\begin{array}{l}0.137^{* * *} \\
(0.00903)\end{array}$ & $\begin{array}{l}0.137^{* * *} \\
(0.00901)\end{array}$ \\
\hline In_credits_ha & $\begin{array}{l}0.0153^{* * *} \\
(0.00234)\end{array}$ & $\begin{array}{l}0.0132^{* * *} \\
(0.00222)\end{array}$ & $\begin{array}{l}0.0131^{* * *} \\
(0.00223)\end{array}$ & $\begin{array}{l}0.0131^{* * *} \\
(0.00222)\end{array}$ \\
\hline Legal Form & $\begin{array}{l}0 \\
(0)\end{array}$ & $\begin{array}{c}0 \\
(0)\end{array}$ & $\begin{array}{c}0 \\
(0)\end{array}$ & $\begin{array}{c}0 \\
(0)\end{array}$ \\
\hline Natural Conditions & - & - & $\begin{array}{c}-0.208^{* * *} \\
(0.0607)\end{array}$ & $\begin{array}{c}-0.190^{* * *} \\
(0.0602)\end{array}$ \\
\hline Year & - & - & - & $\begin{array}{c}-0.0315^{* * *} \\
(0.00684)\end{array}$ \\
\hline Constant & $\begin{array}{c}7.103^{* * *} \\
(0.136) \\
\end{array}$ & $\begin{array}{c}11.32^{* * *} \\
(0.325) \\
\end{array}$ & $\begin{array}{c}11.44^{* * *} \\
(0.327) \\
\end{array}$ & $\begin{array}{c}74.55^{* * *} \\
(13.75)\end{array}$ \\
\hline Observations & 7101 & 7101 & 7101 & 7101 \\
\hline R-squared & 0.019 & 0.099 & 0.100 & 0.103 \\
\hline Number of id & 1196 & 1196 & 1196 & 1196 \\
\hline
\end{tabular}

Source: Own calculation

Robust standard errors in parentheses; ${ }^{* * *} p<0.01,{ }^{* *} p<0.05,{ }^{*} p<0.1$

in the values of coefficients. The model shows quite the same values as the fourth model.

According to the results of each model we can say that there exists the inverse relationship between farm size and production. All increases of farm size led to the decrease of output per hectare. Similar results were reached in the study by Carter (1984). According to his results there is a very strong negative relationship between farm size and productivity, with per hectare production declining nearly $40 \%$ as farm size doubled. This fact says about the increasing return on scale which means that smaller farms are more productive than large ones. Slovak farms should decrease their size of agricultural land to be more productive. Positive impact can be followed in credits. The reason is that if farms have the access to credits, they will invest more money into inputs.

The method of ordinary least squares is insufficient for estimation of coefficients. It can lead to distorted results. In this case it is better to use fixed effect model and random effect model (Heltberg, 1998). We worked with real data so the behaviour of farms is influenced by many other factors which we have to consider in our regression (unobserved effects). To the other factors we can include quality of land, managerial skills, risk, education, own land etc.

The first model consists of two independent variables - farm size in hectares and credits in euro per hectare. According to results of this model we can say that by the increase of farm size by about $1 \%$, output per hectare will decrease by about $10.6 \%$. By the growth of credits per hectare by about $1 \%$, output per hectare will increase by about $1.53 \%$. These variables are statistically significant at significance level $p<0.01$.

In the second model we have a new independent variable - land which considers with non-linear relation between farm size and productivity. Again, we can see from the results of the model that the increase of farm size by about $1 \%$ leads to the decrease of the agricultural output per hectare by about $168.2 \%(p<0.01)$. The credits had again positive influence. If credits increase by about $1 \%$, the output per hectare will increase by about $1.32 \%$ $(p<0.01)$.

The third model contains the Dummy variable - natural conditions. The values of independent coefficients were quite similar as in the second model.
The farms in less favoured areas reached lower production by about $20.8 \%$ $(p<0.01)$ in comparison with farmers operating in productive areas.

In the fourth model there is the Dummy variable - year. This variable explains the changing of production throughout the time. The value of output per hectare will decrease by about $3.15 \%$ at significance level $p<0.01$. Other coefficients showed similar values than the third model.

According to the results of fixed effect model we can confirm the inverse relationship between farm size and productivity. Credits have positive impact on the output per hectare. The production per hectare was lower by farmers who operate in less favoured areas. In the fixed effect model we did not consider the Regions of the Slovak Republic because they do not change in the time.

\section{Conclusion}

The main goal of this paper was to analyse the statistical relationship between productivity and farm size in the Slovak Republic. Many research studies of this issue were conducted in India, Pakistan and Brazil. The question whether small farms are more productive than large farms is important for developed economics and transitive countries from the point of land reform. In the Slovak Republic, large farms have dominant position (500-1000 ha). But is it necessary for Slovak farmers to operate on so many hectares of land? Are these farms productive in comparison with the smaller ones? To achieve the goal of this study we collected the data of output per hectare (revenue item - production), farm size in hectares and credits per hectare in euro from 2004 to 2012. We performed the regression analysis to confirm or refute our hypothesis. Our results of models show that there is a negative relationship between farm size and productivity and positive relationship between credits and productivity. These results were statistically significant in all models at coefficient estimation using the method of least squares and the fixed effect model. According to the reached results we can say that for Slovak farmers it would be better to operate on smaller size of farm than they do. Many studies estimated that in agriculture there are constant returns to scale. In our case we can follow decreasing returns to scale - 
each hectare of land leads to the decrease of production. Positive effect can be follow in credits. Access to credits can depend on farm size. If the amount of credits depends on collateral, then larger farms may have easier access to credits. They can use more inputs and it causes that productivity will depend positively on farm size.

\section{Acknowledgements}

This paper is supported by Vega project 1/0185/15 "Production factor land as an important indicator of agricultural companies".

\section{References}

BHALLA, S. 1979. Farm Size and Productivity and Technical Change in India Agriculture in R A Berry and W R Cline (ed.). Agrarian Structure and Productivity in Developing Countries, Baltimore : John Hopkins University Press, 1979. pp. 141-193.

BHALLA, S. 1988. Does Land Quality Matter? Theory and Measurement. In Journal of Development Economics, vol. 29, 1988, no. 1, pp. 45-62.

BHALLA, S. - ROY, P. 1988. Misspecification in Farm Productivity Analysis : The Role of Land Quality. In Oxford Economic Papers, vol. 40, 1988, no. 1, pp. 55-73.

BHARADWAJ, K. 1974. Notes on Farm Size and Productivity. In Economic and Political Weekly, vol. 9, 1974, no. 13, pp. A11-A24.

CARTER, M. R. 1984. Identification of the Inverse Relationship between Farm Size and Productivity: An Empirical Analyses of Peasant Agricultural Production. In Oxford Economics Papers, New Series, vol. 36, 1984, no. 1, pp. 131 - 145.

CIAIAN, P. 2012. Productivity and farm size. Selective presentation in Slovak Agricultural University in Nitra. Nitra : Slovak Agricultural University, 2012.

CORNIA, G. A. 1985. Farm Size, Land Yields And The Agricultural Production Function: An Analysis For Fifteen Developing Countries. In World Development, vol. 13, 1985, no. 4, pp. 513-534.

DESAI, S. - A. DUBEY - B. JOSHI - M. SEN - A. SHARIFF - R.D. VANNEMAN 2010. Human Development in India: Challenges for a Society in Transition. New Delhi : Oxford University Press, 1996.

DYER, G. 1996. Output Per Acre And Size Of Holding: The Logic Of Peasant Agriculture Under Semi-Feudalism. In Journal of Peasant Studies, vol. 24, 1996, no. 1/2, pp. 103-131.

FAFCHAMPS, M. 1992. Cash Crop Production, Food Price Variability and Rural Market Integration in the Third World. In American Journal of Agricultural Economics, vol. 74, 1992, no. 1, pp. 90-99.
FAN, S. - CONNIE, CH. K. 2005. Is Small Beautiful? Farm Size, Productivity and Poverty in Asian Agriculture. In Agricultural Economics, vol. 32, 2005, Supplements-1, pp. $135-146$.

FEDER, G. 1985. Relation Between Farm Size and Farm Productivity: The Role of Family Labour, Supervision and Credit Constraints. In Journal of Development Economics, 1985, no. 18, pp. 297-313.

GILLIGEN, D. 0. 1998. Farm Size, Productivity, and Economic Efficiency: Accounting for Differences in Efficiency of Farms by Size in Honduras. In American Agricultural Economics Association, Annual Meeting, Salt Lake City, Utah, 1998.

HAVENEVIK, J. K. - SKARSTEIN, R. 1997. Land Tenure, State-Peasant Relations and Productivity in Tanzanian Agriculture in Amit Bhaduri and Rune Skarstein (ed.). Economic Development and Agricultural Productivity, Cheltenham : Edward Elgar, 1997. pp. 183-212.

HELTBERG, R. 1998. Rural Market Imperfections and the Farm Size-Productivity Relationship: Evidence from Pakistan. In World Development, vol. 26, 1998, no. 10, pp. 1807-1826.

MASTERSON, T. 2007. Productivity, technical efficiency and Farm Size in Paraguayan Agriculture. The Levy Economics Institute of Bard College. Working paper no. 490.

ROEMER, J.E. 1982. A General Theory of Exploitation and Class. Cambridge : Harvard University Press.

SEN, A. K. 1962. An Aspect Of Indian Agriculture. In Economic Weekly, vol. 14, 1962, no. 4-6, pp. 243-246.

THAPA, S. 2007. The relationship between farm size and productivity: empirical evidence from the Nepalese mid-hills. Munich Personal RePEc Archive. Paper no. 7638.

ÜNAL GÜL, F. 2008. Small is beautiful: Evidence of an Inverse Relationship between Farm Size and Yield in Turkey. The Levy Economics Institute of Bard College. Working paper no. 551.

VERMA, B. N. - BROMLEY, D.W. 1987. The Political Economy of Farm Size in India: The Exlusive Quest. In Economic Development and Cultural Change, vol. 35, 1987, no. 4, pp. 791-808.

http://ec.europa.eu/agriculture/ricaprod/database/database_en.cfm

\section{Contact addresses}

Ing. Jana Ladvenicová, PhD., Slovak University of Agriculture in Nitra, Faculty of Economics and Management, Department of Economics, Tr. Andreja Hlinku 2, 949 76, Nitra, Slovakia, e-mail: jana.ladvenicova@uniag.sk 